RAFAŁ GERYMSKI

DARIUSZ KROK

Department of Health Psychology and Quality of Life

Institute of Psychology

University of Opole, Poland

\title{
A POLISH ADAPTATION \\ OF THE MULTIDIMENSIONAL EXISTENTIAL MEANING SCALE: \\ INTERNAL STRUCTURE, RELIABILITY, AND VALIDITY
}

The aim of this article was to present a Polish adaptation of the Multidimensional Existential Meaning Scale (MEMS) developed by George and Park (2017). The scale proposes a tripartite view of meaning in life, measuring it in three different dimensions: Comprehension, Purpose, and Mattering, which is a new interesting approach to the conceptualization of this factor from a broader, existential perspective. The scale testing procedure involved a research sample consisting of 401 participants. In addition to the MEMS scale, the Meaning in Life Questionnaire (MLQ) and the Purpose in Life Test (PIL) were used. The results obtained with the Polish version confirmed its reliability and validity, and the three-factor structure. The Cronbach's $\alpha$ coefficient was .91 for the entire scale and oscillated between .72 and .89 for the subscales. The Polish MEMS contains 9 items; therefore, it is a short tool which can be successfully used in research on meaning in life.

Keywords: meaning in life; Polish adaptation; Multidimensional Existential Meaning Scale.

Correspondence concerning this article should be addressed to RAFA£ GERYMSKI, MSc, Department of Health Psychology and Quality of Life, Institute of Psychology, University of Opole, Plac Stanisława Staszica 1, 45-052 Opole, Poland; email: rafal.gerymski@uni.opole.pl; ORCID: https://orcid.org/0000-0003-4847-1429; DARIUSZ KROK, PhD, Hab., Associate Professor at the University of Opole, ORCID: https://orcid.org/0000-0002-1034-0944 


\section{INTRODUCTION}

The psychological functioning of individuals includes many factors that affect their cognitive and emotional processes on both individual and social dimensions. One such factor is meaning in life, which is considered an important element of human behaviour by many psychologists (Frankl, 1979; Martela et al., 2018; Steger, 2012). In thinking about life and making important decisions, people are often guided by the conviction that their existence has certain purposes and directions, either individual (e.g., self-development) or social (e.g., care for the family). They formulate specific aims and goals that determine their general vision of life and provide meaning in life. The purpose of this article is to present a Polish adaptation of the Multidimensional Existential Meaning Scale by examining its internal structure, reliability and validity.

\section{The Role of Meaning in Life}

Meaning in life predominantly refers to an awareness of the importance and purpose of one's life (George \& Park, 2017; Li et al., 2019). The emphasis lies on personal awareness, assessment, and beliefs regarding the overall life of the individual. Providing an accurate definition of meaning in life poses some difficulty as various authors stress different aspects. The first comprehensive theory of meaning in life was formulated by Frankl (1963), who proposed that each person has some unique purpose or overarching aim for their lives and tries to actualize as many values as possible in his/her individual and social life. Yalom (1980) pointed out that meaning in life could be understood in terms of significance; individuals strive to achieve significance and meaning in their life. He also noticed many positive aspects of meaning in life for psychotherapeutic interventions. Examining meaning in life in the context of cognitive psychology, Baumeister (1991) stated that meaning in life depends on purpose, efficacy, value, and self-worth. A considerable body of research revealed that meaning in life plays an important role in many spheres of human functioning as it is related to various aspects of well-being (Russo-Netzer, 2019), indicators of mental health (Steger, 2012), physical health (Park, 2012), and emotional (Martela et al., 2018) and motivational processes (Ünal \& Turgut, 2017).

Recent studies have mainly focused on the conceptualisation of meaning in life in terms of purpose, significance, and goals pursued by individuals (Emmons, 2005; Hooker et al., 2018; Morse \& Steger, 2019). People can experience meaning in life when their lives make sense or convey significant and compre- 
hensible goals. According to Steger (2011), meaning in life can be defined as "the extent to which people comprehend, make sense of, or see significance in their lives, accompanied by the degree to which they perceive themselves to have a purpose, mission, or overarching aim in life" (p. 682). This approach stresses the existence of two dimensions of meaning in life: presence and search. Presence of meaning reflects the degree to which people perceive their lives as significant and meaningful, while search for meaning denotes the extent to which people are engaged in dynamic and active efforts to comprehend significance and purpose in their lives. Both dimensions are characterised by different traits and convey diverse attitudes to life.

This is in line with earlier suggestions formulated by other researchers (Frankl, 1979; Wong, 1998) who pointed to human aspirations needed to obtain a sensible and coherent vision of one's own life. However, in the light of recent research, the first dimension emphasizing the presence of the meaning of life seems to have received more empirical explanation than the second one, which focuses on search for meaning (George \& Park, 2016; Martela \& Steger, 2016). The reason may lie in the fact that what matters most to people is an actually experienced sense of meaningfulness and purposefulness that enables them to find patterns, consistency, and significance in daily events and experiences.

\section{A Tripartite Perspective on Meaning in Life}

George and Park $(2016,2017)$ proposed a tripartite view of meaning in life, which is a new, interesting and valuable approach to the conceptualization of this factor. This approach conceptualises meaning in life in three different dimensions: comprehension, purpose, and mattering. The first dimension (comprehension) reflects the degree to which people perceive a sense of coherence and understanding in their lives (Baumeister, 1991; Wong, 1998). It enables individuals to interpret and systematise their daily experiences, classify important elements of their experience, and constructively recognise necessary information regarding the world and oneself. The comprehension dimension considerably relates to the concept of meaning-making which involves coming to see or understand a given situation from another perspective and re-evaluating one's beliefs and goals to achieve a sense of consistency among them (Park, 2013). Research has demonstrated that meaning-making processes are beneficial for adjustment problems and psychological functioning among war veterans (Currier et al., 2015), coping with stress in adults (Krok, 2015), and attachment and psychological growth in college students (Graci \& Fivush, 2017). The results confirm the 
assumption that having well-defined beliefs about the world and oneself can provide satisfactory explanations which enable people to feel a sense of comprehension.

The second dimension (purpose) represents the extent to which people regard their lives as being focused on and motivated by valued life goals (McKnight \& Kashdan, 2009). The underlying assumption is that goals play a robust motivational role in influencing cognitive processes and regulating human behaviour. Research also reveals that the pursuit of important and cherished valued goals may contribute to well-being (Hennecke \& Freund, 2017). Individuals tend to have unique purposes and overarching aims, which are typically realised in view of one's values and social responsibilities. People characterised by a strong sense of purpose in life have a certain and distinct understanding of the ends they are trying to achieve and are also highly motivated toward their goals. Conversely, those with a weak sense of purpose in life experience feelings of senselessness and disengagement (George \& Park, 2016).

Finally, the third dimension (mattering) reflects the degree to which individuals perceive their existence in terms of significance, importance, and value in the world (George \& Park, 2017). Individuals experience meaning in life when their lives matter to them, in other words they interpret their life events as significant and worthwhile. People with a strong mattering regard their lives as consequential and having long-lasting value, whereas those with a weak mattering feel that their lives make little difference in the world. This dimension is noticeably embedded in the existential approach that stresses the human striving for significance (Yalom, 1980) and terror management theory that highlights the universal desire to achieve and maintain a sense of significance in one's life. Individuals are motivated to establish mental representations that can bind together different external or internal parts of their life, in other words the vision of the world, interpretations of life events, and the self.

The tripartite perspective offers an interesting and valuable approach to examining a multidimensional view of meaning in life. George and Park (2017) advocate that the three dimensions: comprehension, purpose, and mattering can be regarded as the key definitional features of meaning in life that are most often discussed and examined in the literature (George \& Park, 2016; Martela \& Steger, 2016). Individuals who have a high level of meaning in life hold strong beliefs that their lives can be interpreted and organised in a constructive way, and that they have clear and well-defined goals directing their actions and giving them a sense of significance and value. 
To measure the tripartite meaning in life, the Multidimensional Existential Meaning Scale (MEMS) was developed (George \& Park, 2017). It contains the three dimensions discussed above: Comprehension, Purpose, and Mattering. The results of psychometric analyses demonstrated that the scale was a valid and reliable measure of meaning in life; it had a theoretically meaningful factor structure, good reliability, and theoretically consistent convergent and divergent relationships with other relevant variables, like dogmatism, self-concept clarity, behavioural activation, and spirituality. As it is a newly developed scale, it has not been used in many studies (George \& Park, 2017).

\section{The Present Study}

The main goal of the current paper was to examine reliability and validity of the Polish adaptation of the MEMS. In particular, the factorial validity, the reliability (internal consistency), and the construct validity of the MEMS scale were tested on a basis of the analysis of correlations with two external constructs: the Meaning in Life Questionnaire (MLQ; Steger et al., 2006) and the Purpose in Life Test (PIL; Crumbaugh \& Maholick, 1964). First, we tested the factorial validity of the Polish version of the scale by using the confirmatory factor analysis (CFA); we compared the one-factor and three-factor models. Second, we analysed the internal consistency of the scale by using Cronbach's $\alpha$ and McDonald's $\omega$ coefficients. Finally, we examined the validity of the MEMS scale by using the method of content validity and criterion validity.

\section{METHOD}

\section{Participants and Procedure}

The research sample consisted of 402 individuals who were recruited by using the snowball sampling method. The results of one person were excluded due to considerable deficiencies in the responses. Finally, the results of 401 participants were taken into analysis: 147 men (37.7\%) and 254 women $(63.3 \%)$ aged between 18 and $80(M=34.2 ; M e=28 ; S D=14.9)$. Participation in the study was voluntary and anonymous. Every participant gave informed consent to participating in the study. All procedures were performed in accordance with the ethical standards and '64 DoH. 


\begin{abstract}
Measures
Three scales were used in this study. The study participants received a set of questionnaires along with their descriptions.

The subject of validation was the MEMS (George \& Park, 2016). This scale contains 15 items divided into 3 subscales: comprehension, purpose and mattering, which measure meaning in life. Each subscale consists of 5 items rated on a 7-point Likert scale, ranging from 1 (very strongly disagree) to 7 (very strongly agree). In the original study, MEMS scale showed very good reliability (subscales' Cronbach's $\alpha$ was between .84 and .90). The Polish version of the MEMS scale was independently translated by 6 people: English native speakers and researchers in the field of health and personality psychology. Based on the collected translations, the final version of the Polish scale has been established (see Appendix 1).

Two additional scales measuring meaning in life were used in order to validate the Polish version of the MEMS scale. The Meaning in Life Questionnaire (MIL) (Steger et al., 2006) measures two dimensions of meaning in life: presence and search. Each subscale consists of 5 items rated on a 7-point Likert scale, ranging from 1 (strongly disagree) to 7 (strongly agree). Only the presence subscale was used in the current study, according to the original validation of the scale (George \& Park, 2017). The Polish version of the MLQ was adapted by Krok (2011). In the presented study, the scale showed very good reliability (Cronbach's $\alpha=.88$; McDonald's $\omega_{t}=.89$ ).

The Purpose in Life Questionnaire (PIL) (Crumbaugh \& Maholick, 1964) consists of 20 items rated on a 7-point Likert scale. The Polish version of the scale was translated by Płużek (Popielski, 1987). Due to the poor psychometric properties of the individual subscales (see Życińska \& Januszek, 2011), only the total score of meaning in life was taken into analysis. In the current study PIL showed very good psychometric properties (Cronbach's $\alpha=.93$; McDonald's $\left.\omega_{t}=.94\right)$.
\end{abstract}

\title{
RESULTS
}

\section{Descriptive Statistics}

Shapiro-Wilk $(S-W)$ test and descriptive statistics were used in order to examine the characteristics of the variables tested. The $S-W$ test showed that the distribution of all of the variables examined was non-normal. However, the skewness and kurtosis values for all of the tested variables did not exceed 
the range between -2 and 2, which indicates a small asymmetry of the distributions analysed (Kim, 2013). Due to the small asymmetry of the tested distributions and a fairly large sample, parametric analyses were used for the purpose of this article. For more detailed information, see Table 1.

We also decided to verify gender differences among the variables examined. For this purpose, the $t$-test was used. Results showed that there were no significant differences between men and women in the level of meaning in life scores. Cohen's $d$ values for all $t$-test results represented a small effect size (see Table 1).

Table 1. Descriptive Statistics and Results of Gender Comparisons of Selected Variables $(N=401)$

\begin{tabular}{|c|c|c|c|c|c|c|c|c|c|}
\hline & $M$ & $M e$ & $S D$ & Min & $\operatorname{Max}$ & $W$ & $p$ & $S K E$ & $K$ \\
\hline \multicolumn{10}{|l|}{ MEMS } \\
\hline Summary Score & 75.82 & 78.00 & 17.46 & 17.00 & 105.00 & .96 & $<.001$ & -.70 & .34 \\
\hline Comprehension & 26.33 & 27.00 & 5.95 & 6.00 & 35.00 & .94 & $<.001$ & -.89 & .79 \\
\hline Purpose & 27.05 & 28.00 & 6.01 & 6.00 & 35.00 & .94 & $<.001$ & -.88 & .53 \\
\hline Mattering & 22.43 & 23.00 & 7.28 & 5.00 & 35.00 & .98 & $<.001$ & -.32 & -.46 \\
\hline \multicolumn{10}{|l|}{ MLQ } \\
\hline Presence Subscale & 25.63 & 26.00 & 6.53 & 5.00 & 35.00 & .96 & $<.001$ & -.56 & -.20 \\
\hline \multicolumn{10}{|l|}{ PIL } \\
\hline \multirow[t]{3}{*}{ Summary Score } & 104.57 & 108.00 & 20.09 & 30.00 & 140.00 & .96 & $<.001$ & -.74 & .40 \\
\hline & \multicolumn{2}{|c|}{ Men } & \multicolumn{2}{|c|}{ Women } & \multirow{2}{*}{$t_{400}$} & \multirow{2}{*}{$p$} & \multirow{2}{*}{$L L C I$} & \multirow{2}{*}{$U L C I$} & \multirow{2}{*}{$d_{\text {Cohen }}$} \\
\hline & $M$ & $S D$ & $M$ & $S D$ & & & & & \\
\hline \multicolumn{10}{|l|}{ MEMS } \\
\hline Summary Score & 74.63 & 16.77 & 76.95 & 18.30 & -1.26 & .207 & -5.946 & 1.293 & .13 \\
\hline Comprehension & 27.06 & 5.73 & 26.56 & 5.96 & -.81 & .418 & -1.691 & .705 & .08 \\
\hline Purpose & 26.86 & 5.87 & 27.20 & 6.00 & -.55 & .585 & -1.552 & .877 & .06 \\
\hline Mattering & 21.69 & 7.29 & 22.91 & 7.23 & -1.62 & .106 & -2.698 & .259 & .17 \\
\hline \multicolumn{10}{|l|}{ MLQ } \\
\hline Presence Subscale & 25.46 & 6.40 & 25.73 & 6.61 & -.39 & .694 & -1.598 & 1.064 & .04 \\
\hline \multicolumn{10}{|l|}{ PIL } \\
\hline Summary Score & 103.55 & 19.16 & 105.17 & 20.62 & -.78 & .437 & -5.714 & 2.475 & .08 \\
\hline
\end{tabular}

\section{Confirmatory Factor Analysis}

All negative items were reverse scored prior to the analysis. In the first step of psychometric validation, we decided to use the confirmatory factor analysis (CFA). The analysis showed a bad goodness of fit of the one-factor and three- 
factor models based on the collected data (see Table 1). On the basis of modifications indices and semantic similarity of the items, error covariances were set within the Mattering subscale items: 4 with 11 , and 11 with 15 . Goodness of fit indices obtained were not acceptable $(T L I<.95 ; R M S E A>.08)$. On the basis of the factor loadings analysis and modifications indices, items $1,4,6,11,12$, and 14 were removed. This allowed us to obtain a good 9 items three-factor model. For more detailed information, see Table 2.

Table 2. Results of Confirmatory Factor Analysis: Goodness of Fit Measures $(N=401)$

\begin{tabular}{lcccccccc}
\hline & $n_{\text {items }}$ & $\chi^{2}$ & $p$ & CFI & TLI & RMSEA & \multicolumn{2}{c}{ RMSEA 90\% CI } \\
\cline { 7 - 10 } & 16 & 787 & $<.001$ & .849 & .824 & .139 & .130 & .148 \\
Model with 1 factor & 16 & 538 & $<.001$ & .902 & .882 & .114 & .105 & .123 \\
Model with 3 factors & 16 & 376 & $<.001$ & .937 & .922 & .092 & .072 & .092 \\
Model with 3 factors & 9 & 220 & $<.001$ & .920 & .894 & .133 & .117 & .150 \\
plus error covariances & 9 & 50.7 & $<.001$ & .989 & .983 & .052 & .032 & .073 \\
Model with 1 factor & & & & & & &
\end{tabular}

Factor loadings analysis showed that item 2 had lower loading than other items from its subscale. Removing this item lowered the goodness of fit indices, so it was decided to keep that item. Detailed information can be found in Table 3 .

Table 3. Results of Confirmatory Factor Analysis: Factor Loadings $(N=401)$

\begin{tabular}{|c|c|c|c|c|c|c|}
\hline \multirow{2}{*}{ Factor } & \multirow{2}{*}{ Items $^{\mathrm{a}}$} & \multicolumn{2}{|c|}{ Estimate } & \multirow{2}{*}{$S E$} & \multirow{2}{*}{$Z$} & \multirow{2}{*}{$p$} \\
\hline & & UnStd & Std & & & \\
\hline \multirow{3}{*}{ Comprehension } & 7. I know what my life is about & 1.24 & .89 & .06 & 22.39 & $<.001$ \\
\hline & $\begin{array}{l}\text { 8. I can make sense of the things that happen } \\
\text { in my life }\end{array}$ & .99 & .81 & .05 & 19.07 & $<.001$ \\
\hline & 10. I understand my life & 1.27 & .88 & .06 & 21.67 & $<.001$ \\
\hline \multirow{3}{*}{ Purpose } & 3. I have aims in my life that are worth striving for & 1.03 & .81 & .05 & 19.03 & $<.001$ \\
\hline & $\begin{array}{l}\text { 5. I have certain life goals that compel me to keep } \\
\text { going }\end{array}$ & 1.17 & .84 & .06 & 20.07 & $<.001$ \\
\hline & 9. I have goals in life that are very important to me & 1.05 & .86 & .05 & 20.87 & $<.001$ \\
\hline \multirow{3}{*}{ Mattering } & 2. There is nothing special about my existence & .94 & $.49^{\mathrm{b}}$ & .09 & 10.00 & $<.001$ \\
\hline & 13. I am certain that my life is of importance & 1.40 & .93 & .06 & 22.69 & $<.001$ \\
\hline & $\begin{array}{l}\text { 15. Even considering how big the universe is, } \\
\text { I can say that my life matters }\end{array}$ & 1.33 & .72 & .08 & 16.06 & $<.001$ \\
\hline
\end{tabular}

Note. ${ }^{\mathrm{a}}$ items in Polish can be found in the Appendix $1 ;{ }^{\mathrm{b}}$ removal of this item lowered the goodness of fit indices. 


\section{Reliability}

Cronbach's $\alpha$, McDonald's $\omega_{t}$ and $\omega_{h}$ coefficients were used to evaluate internal consistency of the scale. Zinbarg et al. (2005) suggest that $\omega_{h}$ is a much better coefficient than generally used $\alpha$. The $\omega$ coefficient is much more resistant to breaking its assumptions than $\alpha$ coefficient, although it requires a larger sample (Ciżkowicz, 2008; Yang \& Green, 2010).

Calculated measures indicated good reliability of all three subscales. The Comprehension subscale was the scale with highest reliability. The lowest but still acceptable values were obtained for the Mattering subscale. More detailed information is included in Table 4. Reliability for the entire scale was also very good (Cronbach's $\alpha=.91$; McDonald's $\omega_{t}=.94$; McDonald's $\omega_{h}=.85$ ).

Table 4. Results of Reliability and Content Validity Analysis $(N=401)$

\begin{tabular}{|c|c|c|c|c|c|c|c|}
\hline Factor & Items $^{\mathrm{a}}$ & $M$ & $S D$ & $\alpha$ & $\omega_{t}$ & $C V R$ & $C V I$ \\
\hline \multirow{3}{*}{ Comprehension } & 7. I know what my life is about & 5.37 & 1.23 & \multirow{3}{*}{.89} & \multirow{3}{*}{.89} & .99 & \multirow{9}{*}{.80} \\
\hline & $\begin{array}{l}\text { 8. I can make sense of the things that happen } \\
\text { in my life }\end{array}$ & 5.19 & 1.45 & & & .99 & \\
\hline & 10. I understand my life & 5.38 & 1.39 & & & .80 & \\
\hline \multirow{3}{*}{ Purpose } & $\begin{array}{l}\text { 3. I have aims in my life that are worth } \\
\text { striving for }\end{array}$ & 5.74 & 1.27 & \multirow{3}{*}{.87} & \multirow{3}{*}{.88} & .80 & \\
\hline & $\begin{array}{l}\text { 5. I have certain life goals that compel me to } \\
\text { keep going }\end{array}$ & 5.40 & 1.40 & & & .60 & \\
\hline & $\begin{array}{l}\text { 9. I have goals in life that are very important } \\
\text { to me }\end{array}$ & 5.83 & 1.22 & & & .80 & \\
\hline \multirow{3}{*}{ Mattering } & $\begin{array}{l}\text { 2. There is nothing special about my } \\
\text { existence }\end{array}$ & 4.63 & 1.93 & \multirow{3}{*}{.72} & \multirow{3}{*}{.76} & .80 & \\
\hline & 13. I am certain that my life is of importance & 5.29 & 1.51 & & & .99 & \\
\hline & $\begin{array}{l}\text { 15. Even considering how big the universe is, } \\
\text { I can say that my life matters }\end{array}$ & 4.49 & 1.84 & & & .40 & \\
\hline
\end{tabular}

Note. ${ }^{\text {a }}$ items in Polish can be found in Appendix 1.

\section{Validity}

The validity of the MEMS scale was verified by using two methods: content validity and criterion validity. In order to verify the relevance of the MEMS, the content validity ratio (CVR; Lawshe, 1975) was used. Questions selected in factor analysis were judged by 10 researchers who specialised in the field of health and personality psychology. Before assessing the questions, judges were introduced to the theoretical background of meaning in life. Lawshe's CVR is calcu- 
lated by the formula presented in Figure 1, where $n$ is a number of judges which indicate an item as essential and $N$ is a total number of judges. Content Validity Index $(C V I)$ can be calculated afterwards. It is the mean of the CVR values of the retained items.

$$
C V R=\frac{n-N / 2}{N / 2}
$$

Figure 1. CVR formula (Lawshe, 1975)

$C V R$ and $C V I$ measures demonstrate positive values. This allowed us to prove that all questions were accurate from a theoretical point of view. For more detailed information, see Table 4.

Criterion validity of MEMS was measured by using Pearson's $r$ correlation coefficient. It was decided to verify the relationship between the MEMS and other measures of meaning in life-MLQ and PIL. The MEMS total score and its subscales were significantly correlated with the MLQ's Presence of Life subscale and the PIL total score. The effect size coefficients indicated a positive and strong relationship between those constructs (see Table 5).

Table 5. Results of Criterion Validity Analysis: Pearson's $r$ Correlation $(N=401)$

\begin{tabular}{lcccccc}
\hline & 1. & 2. & 3. & 4. & 5. & 6. \\
\hline 1. MEMS: Summary Score & - & & & & \\
2. MEMS: Comprehension & .90 & - & & & & \\
3. MEMS: Purpose & .89 & .74 & - & & \\
4. MEMS: Mattering & .90 & .70 & .68 & - & \\
5. MLQ: Presence Subscale & .79 & .74 & .72 & .69 & - & .70 \\
6. PIL: Summary Score & .81 & .75 & .71 & .72 &. \\
\hline
\end{tabular}

Note. All correlations statistically significant at $p<.001$. 


\section{DISCUSSION}

The aim of this article was to validate the Polish version of the MEMS (George \& Park, 2016). For this purpose, the confirmatory factor analysis, reliability analysis using $\alpha$ and $\omega$ coefficients, and two measures of validity (content and criterion validity) were used on a sample of 401 participants. The Polish version of the scale turned out to be a valid and reliable tool.

Our analyses confirmed a good fit of the three-factor model, which is consistent with the original validation (George \& Park, 2016). All of the proposed goodness of fit coefficients (except $\chi^{2}$ ) exceeded the limit values in the case of the three-factor model consisting of nine items. This result differs from the original validation of the scale, in which the three-factor model consisting of 15 items turned out to be best fit. CFI and RMSEA coefficients in the Polish 9-item adaptation presented in our study show better fit to the data than the original George and Park's 15-item scale. The 9-item adaptation seems to be capable of efficiently capturing the understanding of how people attempt to find meaning in their lives. As discussed, one approach in the use of meaning in life judgments (Martela \& Steger, 2016) is to ask participants how they understand significance and meaningfulness found in their life with a limited number of questions. Too many alternatives can somehow spoil theoretical definitions of meaning in life and may give rise to conceptual ambiguity.

However, the question remains why some of the items from the original MEMS scale were not found in the Polish adaptation. One answer can be found in the sphere of cultural differences between the US (the country in which the MEMS was developed) and Poland. Some of the original items (e.g., "Even a thousand years from now, it would still matter whether I existed or not" or "Whether my life ever existed matters even in the grand scheme of the universe") may have had different semantic and linguistic connotations/associations in the Polish context, which in turn, made them not achieve the factor loadings required to be included in our adaptation.

Two domains appear to play a significant role in the cultural interpretations of the items. First, there may be differences between the American and Polish populations in relation to long-term and short-term goals (the Purpose dimension). American culture is considered to value individualism, while Poland still represents a mixture of individualistic and collectivistic values (Radkiewicz, 2017). Therefore, Americans could predominantly focus on pursuing goals related to their personal life, career, or individual preferences, while Poles could concentrate on both individualistic goals and the goals related to their societal 
obligations or preferences. Second, the American and Polish populations are likely to have different understandings of well-being, spiritual life, and the importance of individual life (the Mattering dimension), due to the fact that each culture represents the unifying principle of many interconnected and interrelated values. As American culture is more focused on such values as personal freedom, liberty, and individualism than the Polish one, these cultural differences are likely to influence the understanding of the MEMS items in both countries. Specifically, it was a matter of construct equivalence, which occurs when the same underlying construct and nomological network across cultural groups cannot be defined in the same way (Hambleton \& Zenisky, 2011). As the items mentioned above referred to very idiosyncratic, existential issues, their semantical range was apparently different.

The Polish adaptation turned out to be a reliable and valid scale. The $\alpha$ and $\omega$ coefficients exceeded .70, which indicates the consistency of the scale validated. These results are very similar to the original version of the scale. The Comprehension subscale was the one with the highest reliability. The lowest, but still acceptable reliability had the Mattering subscale. The validity measure using $C V R$ and $C V I$ indicates that the scale items fit well into the concept of meaning in life. The correlations of the MEMS subscales and other tools for measuring meaning of life (MLQ and PIL) were positive and strong, which indicates that the validity of the Polish adaptation was good. MLQ and PIL scores were the most strongly related to the MEMS Comprehension subscale.

However, the comparison of the MEMS with MLQ and PIL demonstrates noticeable differences in measuring the level and structure of meaning in life by the scales. The presence subscale of the MLQ (Steger et al., 2006) and the PIL (Crumbaugh \& Maholick, 1964) tend to measure meaning in life unidimensionally, providing a single global score. As a consequence, those scales combine different dimensions of meaning in life and prevent any form of examining their relationships with other factors. In contrast, the MEMS enables researchers to analyse meaning in life within three distinct dimensions: comprehension, purpose, and mattering, which offers a broader perspective in research on personality and well-being. Additionally, the MEMS, including comprehension, purpose, and mattering is able to efficiently capture the three crucial features of meaning in life that are most often studied within the broader literature on meaning: coherence, goals, and values (Baumeister, 1991; Emmons, 2005; Martela \& Steger, 2016; Park, 2017). The other two scales offer rather a different approach, either giving a global perspective on meaning in life (MLQ) or describing very specific areas (like life attitudes, life purpose, or life autonomy) in which meaning in life 
manifests itself (PIL). Given the different methodological foundations of the above scales, combining them in one study could provide an optimal solution to measuring meaning in life.

Our findings imply that the MEMS scale, together with its three underlying dimensions, offers valuable utility in regard to measuring meaning in life conceptualised in terms of comprehension, purpose, and mattering. In addition, the three dimensions are not redundant factors, but can be distinguished from one another. The concept of meaning in life embedded in the MEMS conceptual framework seems to provide a unifying perspective for understanding how people perceive both themselves and their worlds in terms of significance and meaning (George \& Park, 2016; Krok, 2015; Martela et al., 2018). The internal components of meaning in life organise and prioritise the most crucial information regarding different domains of life and the interactions occurring between oneself and the world. Especially, the mattering dimension is a very promising factor for psychological explorations of meaning in life as it enables researchers to examine people's lives in terms of significance, importance, and value in the world.

Although our study produced a reliable and valid scale, it is not devoid of limitations. Despite the fact that the tested sample meets the requirements of psychometric validation (at least $N=10$ per item) and CFA (at least $N=200$ ), it is not fully representative (Gerymski \& Krok, 2019). The sample collected in our study $(N=401)$ is only a small part of the population. In addition, the trial was not a clinical one. It is difficult to predict how the current scale could work in groups of clinical patients or people undergoing psychotherapy. The lack of examination of demographic variables did not allow us to analyse the collected data more in depth. Perhaps, if the results were divided by education or marital status, the proposed models would differ. Furthermore, the Polish version of the MEMS contains 3 subscales, each consisting of 3 items. In the original version, each subscale consisted of 5 items. This limits the direct comparison of the results obtained using the original and Polish versions of the scale.

To conclude, the present study was focused on the validation of a new scale measuring meaning in life. The new approach to investigating meaning in life will permit a more thorough examination of this sphere. Meaning in life is an unquestionably very popular and exploratively useful factor in the studies of personality psychology (Steger et al., 2008), mental and physical health (Hooker et al., 2018), and well-being (Krok, 2018). Therefore, the Polish version of the scale offers a new insight into the further exploration of the sphere of meaning in life and its related constructs. 


\section{REFERENCES}

Baumeister, R. F. (1991). Meanings of life. Guilford.

Ciżkowicz, B. (2018). Omega McDonalda jako alternatywa dla alfa Cronbacha w szacowaniu rzetelności testu [McDonald's omega as an alternative to Cronbach's alpha in scale score reliability estimation]. Polskie Forum Psychologiczne, 23(2), 311-329.

Crumbaugh, J. C., \& Maholick, L. T. (1964). An experimental study in existentialism: The psychometric approach to Frankl's concept of noogenic neurosis. Journal of Clinical Psychology, 20, 200-207.

Currier, J. M., Holland, J. M., \& Malott, J. (2015). Moral injury, meaning making, and mental health in returning veterans. Journal of Clinical Psychology, 71(3), 229-240.

Emmons, R. (2005). Striving for the sacred: Personal goals, life meaning, and religion. Journal of Social Issues, 61, 731-745.

Frankl, V. E. (1963). Man's search for meaning: An introduction to logotherapy. Washington Square Press.

Frankl, V. E. (1978). Nieuświadomiony Bóg [Unaware God]. Pax.

George, L. S., \& Park, C. L. (2016). Meaning in life as comprehension, purpose, and mattering: Toward integration and new research questions. Review of General Psychology, 20(3), 205-220.

George, L. S., \& Park, C. L. (2017). The multidimensional existential meaning scale: A tripartite approach to measuring meaning in life. The Journal of Positive Psychology, 12(6), 613-627.

Gerymski, R., \& Krok, D. (2019). Psychometric properties and validation of the Polish adaptation of the Light Triad Scale. Current Issues in Personality Psychology, 7(4), 341-354.

Graci, M. E., \& Fivush, R. (2017). Narrative meaning making, attachment, and psychological growth and stress. Journal of Social and Personal Relationships, 34(4), 486-509.

Hambleton, R. K., \& Zenisky, A. L. (2011). Translating and adapting tests for cross-cultural assessments. In D. Matsumoto \& F. J. R. van de Vijver (Eds.), Culture and psychology. Crosscultural Research methods in psychology (pp. 46-74). Cambridge University Press.

Hennecke, M., \& Freund, A. M. (2017). The development of goals and motivation. In J. Specht (Ed.), Personality development across the lifespan (pp. 257-273). Elsevier.

Hooker, S. A., Masters, K. S., \& Park, C. L. (2018). A meaningful life is a healthy life: A conceptual model linking meaning and meaning salience to health. Review of General Psychology, 22(1), 11-24.

Kim, H. Y. (2013). Statistical notes for clinical researchers: assessing normal distribution (2) using skewness and kurtosis. Restorative Dentistry \& Endodontics, 38(1), 52-54.

Krok, D. (2011). Poczucie sensu życia a dobrostan psychiczny [Meaning in life and psychological well-being]. Psychologia Jakości Życia, 10(2), 95-115.

Krok, D. (2015). Religiousness, spirituality, and coping with stress among late adolescents: A meaning-making perspective. Journal of Adolescence, 45, 196-203.

Krok, D. (2018). When is meaning in life most beneficial to young people? Styles of meaning in life and well-being among late adolescents. Journal of Adult Development, 25(2), 96-106.

Lawshe, C. H. (1975). A quantitative approach to content validity. Personnel Psychology, 28(4), 563-575.

Li, P. J., Wong, Y. J., \& Chao, R. C. L. (2019). Happiness and meaning in life: Unique, differential, and indirect associations with mental health. Counselling Psychology Quarterly, 1-19. 
Martela, F., \& Steger, M. F. (April 2016). The three meanings of meaning in life: Distinguishing coherence, purpose, and significance. The Journal of Positive Psychology, 11(5), 531-545.

Martela, F., Ryan, R. M., \& Steger, M. F. (2018). Meaningfulness as satisfaction of autonomy, competence, relatedness, and beneficence: Comparing the four satisfactions and positive affect as predictors of meaning in life. Journal of Happiness Studies, 19(5), 1261-1282.

McKnight, P. E., \& Kashdan, T. B. (2009). Purpose in life as a system that creates and sustains health and well-being: An integrative, testable theory. Review of General Psychology, 13, 242-251.

Morse, J. L., \& Steger, M. F. (2019). Giving birth to meaning: Understanding parenthood through the psychology of meaning in life. In O. Taubman Ben-Ari (Ed.), Pathways and Barriers to Parenthood (pp. 1-17). Springer.

Park, C. L. (2012). Meaning, spirituality, and growth: Protective and resilience factors in health and illness. In A. S. Baum, T. A. Revenson, \& J. E. Singer (Eds.), Handbook of health psychology (pp. 405-430). Sage.

Park, C. L. (2013). The meaning making model: A framework for understanding meaning, spirituality, and stress-related growth in health psychology. European Health Psychologist, $15(2), 40-47$.

Park, C. L. (2017). Distinctions to promote an integrated perspective on meaning: Global meaning and meaning-making processes. Journal of Constructivist Psychology, 30(1), 14-19.

Popielski, K. (1987). Testy egzystencjalne: metody badania frustracji egzystencjalnej i nerwicy noogennej [Existential tests: Methods of studying existential frustration and noogenic neurosis]. In K. Popielski (Ed.), Człowiek - pytanie otwarte [Man - An open question] (pp. 237-261). Redakcja Wydawnictw KUL.

Pyszczynski, T., Greenberg, J., \& Solomon, S. (1999). A dual-process model of defense against conscious and unconscious death-related thoughts: An extension of terror management theory. Psychological Review, 106(4), 835-845.

Radkiewicz, P. (2017). Ideological inconsistencies on the left and right as a product of coherence of preferences for values. The case of Poland. Polish Psychological Bulletin, 48(1), 93-104.

Russo-Netzer, P. (2019). Prioritizing meaning as a pathway to meaning in life and well-being. Journal of Happiness Studies, 20(6), 1863-1891.

Steger, M. F. (2011). Meaning in life. In S. J. Lopez \& C. R. Snyder (Eds.), Oxford handbook of positive psychology (pp. 679-687). Oxford University Press.

Steger, M. F. (2012). Experiencing meaning in life: Optimal functioning at the nexus of well-being, psychopathology, and spirituality. In P. T. P. Wong (Ed.), The Human quest for meaning: Theories, research, and applications (pp. 165-184). Routledge.

Steger, M. F., Frazier, P., Oishi, S., \& Kaler, M. (2006). The meaning in life questionnaire: Assessing the presence of and search for meaning in life. Journal of Counseling Psychology, 53, 80-93.

Steger, M. F., Kashdan, T. B., Sullivan, B. A., \& Lorentz, D. (2008). Understanding the search for meaning in life: Personality, cognitive style, and the dynamic between seeking and experiencing meaning. Journal of Personality, 76(2), 199-228.

Ünal, Z. M., \& Turgut, T. (2017). The existential motivation: Searching for meaning - The contribution of meaningful work on meaning in life. Methods, 20(1), 1-8.

Wong, P. T. P. (1998). Implicit theories of meaningful life and the development of the Personal Meaning Profile (PMP). In P. T. P Wong \& P. Fry (Eds.), Handbook of personal meaning: Theory, research, and practice (pp. 111-140). Lawrence Erlbaum. 
Yalom, I. D. (1980). Existential psychology. Basic Books.

Yang, Y., \& Green, S. B. (2010). A note on structural equation modeling estimates of reliability. Structural Equation Modeling, 17(1), 66-81.

Zinbarg, R. E., Revelle, W., Yovel, I., \& Li, W. (2005). Cronbach's $\alpha$, Revelle's $\beta$, and McDonald's $\omega \mathrm{H}$ : Their relations with each other and two alternative conceptualizations of reliability. Psychometrika, 70(1), 123-133.

Życińska, J., \& Januszek, M. (2011). Test Sensu Życia (Purpose in Life Test, PIL) JC Crumbaugha i LT Maholicka: Analiza psychometryczna [Purpose in Life Test (PIL) by J. C. Crumbaugh and L. T. Maholick: A psychometric analysis]. Czasopismo Psychologiczne, 17(1), 133-142. 


\section{Appendix 1}

\begin{tabular}{|c|c|c|}
\hline & $\begin{array}{l}\text { The original version of the scale } \\
\text { (George \& Park, 2017) }\end{array}$ & $\begin{array}{l}\text { The Polish version of the scale } \\
\text { (Gerymski \& Krok, 2020) }\end{array}$ \\
\hline 1. & My life makes sense & Moje życie ma sens \\
\hline 2. & There is nothing special about my existence & 2. Nie ma nic nadzwyczajnego w moim istnieniu \\
\hline 3. & I have aims in my life that are worth striving for & $\begin{array}{l}\text { 3. Mam w swoim życiu cele, do których warto } \\
\text { dążyć }\end{array}$ \\
\hline 4. & $\begin{array}{l}\text { Even a thousand years from now, it would still } \\
\text { matter whether I existed or not }\end{array}$ & $\begin{array}{l}\text { 4. Nawet za tysiąc lat, wciąż będzie miało } \\
\text { znaczenie, czy istniałem }\end{array}$ \\
\hline 5. & $\begin{array}{l}\text { I have certain life goals that compel me to keep } \\
\text { going }\end{array}$ & $\begin{array}{l}\text { 5. Mam konkretne cele w życiu, które motywują } \\
\text { mnie do działania }\end{array}$ \\
\hline 6. & I have overarching goals that guide me in my life & $\begin{array}{l}\text { 6. Mam nadrzędne cele, które prowadzą mnie } \\
\text { przez życie }\end{array}$ \\
\hline 7. & I know what my life is about & 7. Wiem, na czym polega moje życie \\
\hline 8. & $\begin{array}{l}\text { I can make sense of the things that happen in my } \\
\text { life }\end{array}$ & $\begin{array}{l}\text { 8. Potrafię nadać sens rzeczom, które dzieją się } \\
\text { w moim życiu }\end{array}$ \\
\hline 9. & I have goals in life that are very important to me & $\begin{array}{l}\text { 9. Mam w życiu cele, które są dla mnie bardzo } \\
\text { ważne }\end{array}$ \\
\hline 10. & I understand my life & 10. Rozumiem swoje życie \\
\hline 11. & $\begin{array}{l}\text { Whether my life ever existed matters even in the } \\
\text { grand scheme of the universe }\end{array}$ & $\begin{array}{l}\text { 11. Fakt, że kiedykolwiek istniałem ma znaczenie } \\
\text { nawet wobec ogromu wszechświata }\end{array}$ \\
\hline 12. & My direction in life is motivating to me & $\begin{array}{l}\text { 12. Kierunek mojego życia jest dla mnie moty- } \\
\text { wujący }\end{array}$ \\
\hline 13. & I am certain that my life is of importance & 13. Jestem pewien, że moje życie ma znaczenie \\
\hline 14. & $\begin{array}{l}\text { Looking at my life as a whole, things seem clear } \\
\text { to me }\end{array}$ & $\begin{array}{l}\text { 14. Patrząc na moje życie jako całość, wszystko } \\
\text { wydaje mi się zrozumiałe }\end{array}$ \\
\hline 15. & $\begin{array}{l}\text { Even considering how big the universe is, I can } \\
\text { say that my life matters }\end{array}$ & $\begin{array}{l}\text { 15. Nawet uwzględniając wielkość wszechświata, } \\
\text { mogę powiedzieć, że moje życie ma znaczenie }\end{array}$ \\
\hline
\end{tabular}




\section{Appendix 2}

\section{Wielowymiarowa Skala Sensu Egzystencjalnego MEMS \\ (adaptacja: Gerymski \& Krok, 2020)}

Instrukcja: Poniżej znajdują się twierdzenia odnoszące się do Pana/Pani życia. Proszę uważnie przeczytać każde z twierdzeń i określić, w jakim stopniu zgadza lub nie zgadza się Pan/Pani z nim, zakreślając kółkiem wybraną cyfrę spośród znajdujących się obok twierdzenia. Proszę odpowiadać według poniższej skali:

$\underline{7}$ - zdecydowanie zgadzam się

$\underline{6}-$ zgadzam się

5 - raczej zgadzam się

4 - nie mam zdania

$\underline{\underline{3}}$ - raczej nie zgadzam się

$\underline{2}$ - nie zgadzam się

$\underline{1}$ - zdecydowanie nie zgadzam się

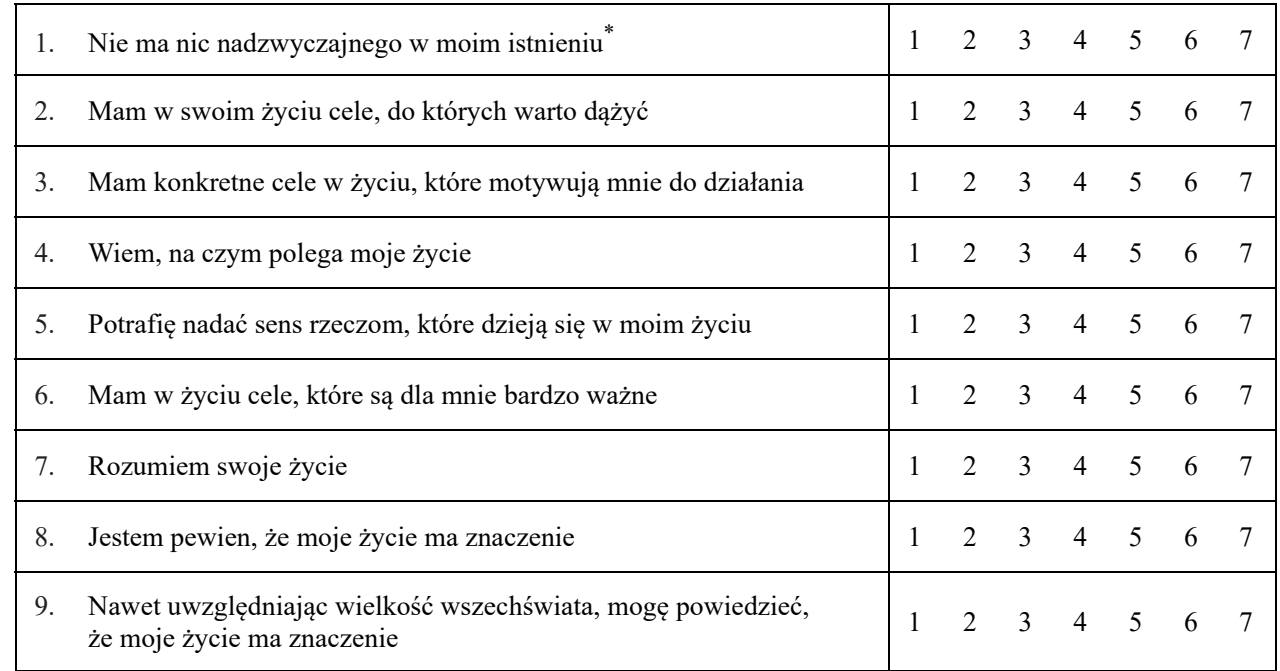

* Item odwrócony:

Zrozumienie $=4,5,7$

$\mathrm{Cel}=2,3,6$

Znaczenie $=1,8,9$ 